\section{Explosive Hail.}

ON the afternoon of November II, IgII, there was a brief storm of explosive hail at this place.

The morning had been unseasonably warm; about noon there were the usual signs of a coining thunderstormheavy cumulo-nimbus clouds with a gusty wind-which began about $2.30 \mathrm{p} . \mathrm{m}$. with a slight shower of heavy raindrops; shortly afterwards there were two or three flashes of lightning and thunder, followed by a fall of large hailstones, which on coming in contact with the windows or walls or pavement in many instances exploded with a sharp report, so loud as to be mistaken for breaking window panes or a pistol shot. As the hail fell, the frag ments sprang up from the ground and flew in all directions, looking like a mass of "popping corn" on a large scale.

The fall lasted two or three minutes, about half the hailstones being shattered, the ground in some places being nearly covered white with the stones and fragments.

Of the unbroken stones, seventy were gathered. They weighed, roughly, 225 grams. A few were ellipsoidal, the longest axis about $25 \mathrm{~mm}$. in length; most of them, however, were nearly spherical, and somewhat smaller, from 15 to $20 \mathrm{~mm}$. in diameter.

Practically all of them contained a nucleus. In a few of the stones the nucleus was porcelain-like, raspberryshaped, surrounded by almost colourless spherical layer of ice, for about five-sevenths of the diameter, and then a shell of porcelain-like, snowy ice.

A fair proportion of the stones showed, in addition to the spherical, a radiate structure, which was very apparent as the stones melted in a flat dish, showing the crosssection with great distinctness.

The writer noticed a similar fall of explosive hail about eighteen years ago at Lexington, Virginia. The stones in this fall were much smaller, and attention was directed to the stones by the peculiar way in which they seemed to rebound on striking the ground, which was also due on that occasion to their breaking into fragments, without, however, any noticeable explosion.

University of Missouri, Columbia, Mc., W. G. BROWN. December 27, rgII.

THE BEGINNING OF ARCTIC EXPLORATION.1 THESE two great volumes take up the knowledge of the northern regions from the dawn of history, and starting from Homer they have only reached the voyage to Newfoundland of Gaspar Corte-Real in 1503. The reason for this is thus explained, not in the preface, but in the "Conclusion":-

"If we would discover how a watercourse is formed, from the very first bog-streams up in the mountain, we must follow a multitude of tiny rills, receiving one fresh stream after another from every side, running together into burns, which grow and grow and form little rivers till we come to the end of the wooded hillside and are suddenly face to face with the great river in the valley below.

"A similar task confronts him who endeavours to explore the first trickling rivulets of human knowledge; he must trace all the minute, uncertain, often elusive beginnings, follow the diversity of tributaries from all parts of the earth, and show how the mass of knowledge increases constantly from age to age, sometimes reposing in long stretches of dead water, half-choked with peat and rushes, at other times plunging onward in foaming rapids. And then he too is rewarded; the stream grows broader and broader, until he stands beside the navigable river."

Dr. Nansen takes us with him as he traces the head streams of the earliest knowledge of the north in the misty uplands of the past, and leaves us just where the historian can advance with some assurance. He points out how the early peoples had vague ideas of shadowy regions on the edge of the habitable world-

1 "In Northern Mists: Arctic Exploration in Early Times." By Prof, F. Nansen, G.C.V.O. Translated by A. G. Chater. Vol. i., pp. xii $3^{8} 4$ Vol. ii., pp. iv +416 . (London: Wm. Heinemann, Igrr.) 'Two volumes, 3os. net.

NO. 2202, VOL. 88 disc, and how, though now and again a voyager placed solid facts on record, such details as were current regarding the northern lands were for the most part a mixture of legend and myth. The writers who have dealt with the history of Arctic exploration hitherto have usually commenced with the search for the north-west and the north-east passages which supplied a powerful and intelligible motive for centuries of struggle. This record concludes before that motive came into play; but a book on the history of exploration without some clue of continuous human interest would be a weary chaos of random incidents, which no reader would willingly face, and Dr. Nansen finds a unifying clue in the persistent, romantic, and everhopeful search for the Fortunate Isles, which lay or drifted throughout the mistiest periods of history just on the verge of the known world. The guiding principle for the elucidation of the beginnings of exploration seems to be implied in this piece of psychology.

"For one thing, man's power of grasping reality varies greatly; in primitive man it is clouded to a degree which we modern human beings can hardly understand. $\mathrm{He}$ is

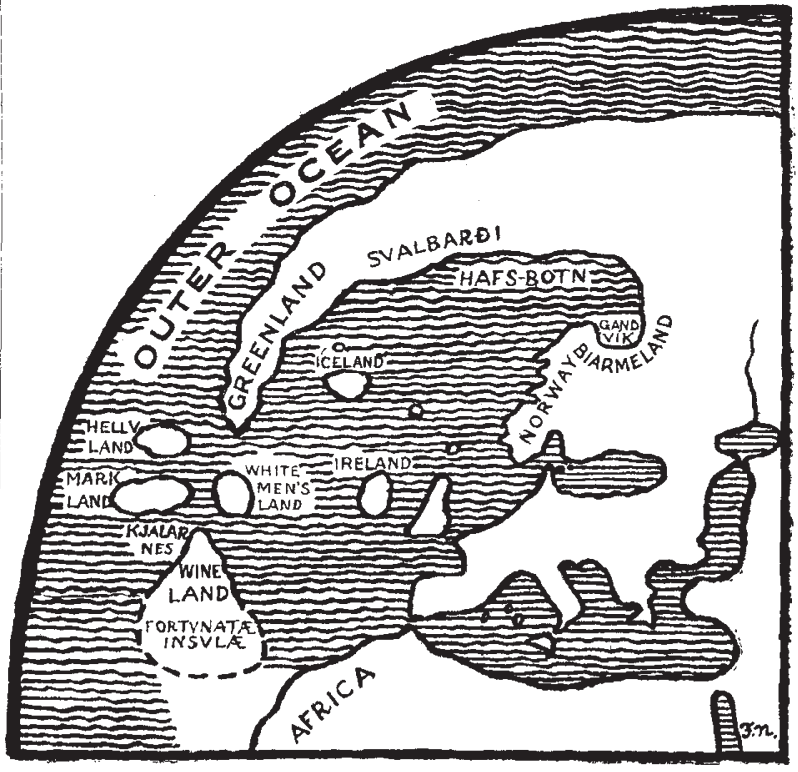

The conception of the northern and western lands and islands in Norse literature. From "In Northern Mists."

as yet incapable of distinguishing between idea and reality, between belief and knowledge, between what he has seen and experienced and the explanation he has provided for his experience."

Dr. Nansen proceeds to retell the old stories with this distinction always in his mind, and in the endeavour to separate fact from expectation he finds a way of escape from the clamour of the partisans who have so frequently made out the dim heroes of early voyages and their first chroniclers to be either paragons of veracity and precision or shameless and aimless liars. There is an appeal to the most authentic versions of the early narratives, many of which are given in these pages more completely than ever before in translation, and there is a minimum-we had almost said an absence-of controversial statements directed against the holders of contrary views.

It should be explained that the quotations from early authorities are all in translation, and the very interesting maps or portions of maps which are reproduced are translations also in so far as they are not facsimiles, but representations of the meaning of the maps, in many cases without the conventional repre- 
sentations or the networks of compass lines which make the originals often both indistinct and confusing. Thus Dr. Nansen does not invite criticism of his interpretation of documents except from the very few who have made a special study of one or other of the many lines of literary or cartographic investigation with which he deals. Our knowledge of Dr. Nansen's character and of the fact that he went into the enormous labour of this work without prejudice or prepossession gives us confidence in the soundness of his conclusions.

The early history of the north, apart from vague poetical allusions, rests upon only a few definite authorities. The first is Pytheas, the Phocean colonist in Massalia, who first ventured northwards in the Atlantic, about 330 B.C., circumnavigated the British Isles, and reached Thule; he was also the first navigator to fix positions by astronomical determinations of latitude by means of a gnomon or by ascertaining the length of the longest day. Dr. Nansen goes fully into the question of the position of Thule, and satisfies himself that it was not Shetland or Faroe or Iceland but Norway. The next definite information was the description given to King Alfred about 890 A.D. (by the Norwegian walrus-hunter Ottar) of the rounding of the North Cape, the entry into the White Sea, and the phenomenon of the midnight sun. This was obviously a truthful narrative of personal experience. Then came Adam of Bremen about ro7o, who collected a great deal of authentic information regarding Scandinavia, and mentions Iceland, Greenland, and Wineland, the two last-named for the first time in literature; but there is also much of the fabulous in his writings derived from classical legends. Contemporaneously with the chroniclers, and in the centuries between them, there were two vague currents of northern exploration regarding which such knowledge as has emerged is of the mistiest. They were those of the Irish monks, who founded a chain of settlements from the Hebrides to Iceland and carried with them legends of $\mathrm{Hy}$ Breasail-the Isle of the Blessed or the Fortunate Isles of the Greeks-of which many adventurous souls went in search; the finding of which was often rumoured but never confirmed. The second current was that of the Norsemen, who sailed westward to Iceland, where they found Irish monks residing, and whence, pushing westward still, they reached and colonised southern Greenland.

The old Icelandic sagas speak, as is well known, of a voyage of Leif Ericsson, when he missed Greenland and sailed westward until he met a coast, parts of which were named Helluland, Markland, and.Wineland the Good, where self-sown wheat and wild vines were found, and various remarkable encounters took place. Hitherto the sagas have been accepted as faithful tradition enshrining facts of observation, but the outcome of a prolonged examination of all possible data is to convince Dr. Nansen that the wheat, the vines, and many other features were mere products of expectation on the part of the saga-tellers. He allows that Norsemen did reach the American coast (though we must say that his iconoclastic logic, if carried further, seems to us capable of throwing doubt on the authenticity of this part of the narrative too), but he believes that they thought they had reached the Fortunate Isles spoken of by the Irish monks and the Roman legends, and so attributed all that the Fortunate Isles were supposed to be to the lands of their discovery.

The idea that Wineland, though reached from Greenland, lay so far along the rim of the world-disc that it was close to Africa brings it in line with the Mediterranean legend, and presented no difficulty to NO. 2202, VOL. 88$]$ the mediæval geographers before the revival of the spherical form of the earth and the invention of portable instruments for the astronomical determination of latitude. The growth of knowledge of cosmography and of precision in cartography is traced down to the time of the Cabots and the Corte-Reals, and the period of commercial whaling on the small scale which led the northern seafarers to the edge of the arctic ice is touched upon; and then, when the globe had been swept clear of myth and the Fortunate Isles had gone to Davy Jones with the Sunken Land of Busse, Dr. Nansen leaves us with the stage free for modern exploration. What he said of the explorers of that sixteenth-century stage we may say of those of our twentieth-century stage, when the passages have been found and the pole itself reached-

"To riches men have seldom attained, to the Fortunate Isles never; but through all we have won knowledge."

H. R. M.

\section{MICROSCOPE STANDS.}

II.

The Changes now going on.

$\mathrm{I}$ discussing the relative merits of Continental versus English pattern microscopes, the ground is at once cleared if we discard the labels Continental and English, and seek a more accurate definition for each type than merely the place of origin.

As a matter of fact, the old labels will soon cease to have any real meaning, for the Continental makers are adding to their patterns new instruments, rivalling in complexity of adjustments the so-called English type, and English makers are in many instances producing almost exact replicas of the Continental type. That the foot still remains of a more or less horseshoe form, with inclination axis below the stage, in the one, and is generally of the tripod form with inclination axis above the stage in the other, is a detail which does not affect the real difference between the two types, viz. relative complexity, although it renders the former more suitable for use in the vertical, and the latter more comfortable for use in an inclined position.

The English type of microscope, owing to the fostering care of a small body of dilettanti, came into general notice, when the need of a microscope was felt by the professions, already a complex instrument; from this simpler types have been slowly evolved, too slowly unfortunately for the demand, which has in consequence swung over to the Continental type, which, having no past to speak of, was able to adapt itself the more readily to the wants of those who did not care so much how they saw, so long as they could see.

The two types, starting from opposite poles, have lately reached common ground as regards the majority of the instruments produced, and there is little to choose between them for mere demonstration of known structure; but to get the finest results out of any optical system centration along the axis, and in the case of a microscopical system interchangeability of parts not only above but below the stage is essential, and few Continental microscopes possess the means of doing this, while every English stand of the first class is so provided.

Therefore the conclusion of any unbiassed observer must be that the English type is the better in the hands of the expert, who wishes not merely to demonstrate the known, but to reach out maybe into the unknown. but what is best for the master of his instrument and subject is not always good for the average man, and 1 The first article appeared in Nature of Decemher $2 \pi$, 19tr. 